\title{
Size distribution of chlorophyll a biomass and primary production in a temperate estuary (Southampton Water): the contribution of photosynthetic picoplankton
}

\author{
Arantza Iriarte*, Duncan A. Purdie \\ Department of Oceanography, University of Southampton, Highfield, Southampton SO9 5NH, United Kingdom
}

\begin{abstract}
Size-fractionated chlorophyll a (chl a) biomass and primary production rate $(>3 \mu \mathrm{m}$, 1-3 $\mu \mathrm{m}$ and $<1 \mu \mathrm{m}$ ) and picophytoplankton abundance (both prokaryotic and eukaryotic) were investigated in Southampton Water (south coast of England), with routine sampling at 2 stations, representative of conditions in the mid and outer estuary. In the mid estuary the cycle of chl a biomass in the $>3 \mu \mathrm{m}$ size fraction was characterized by a small spring peak and a more intense summer peak. In the outer estuary a chl a maximum in the $>3 \mu \mathrm{m}$ size fraction occurred in spring; phytoplankton in this size fraction may have been nutrient limited in summer at this station. Phycoerythrin-containing picocyanobacteria, eukaryotic picophytoplankton cell numbers, and chl a biomass and primary production rate by the $<1 \mu \mathrm{m}$ size fraction all showed a positive correlation with temperature and peaked during summer at both stations. The $1-3$ and $<1 \mu \mathrm{m}$ size fractions contributed around 14 and $6 \%$, respectively, to the estimated annual rate of depth-integrated plankton community primary production. These results suggest that the impact of the photosynthetic picoplankton diminishes in an increasing eutrophication gradient, from offshore (>50\%) to coastal (ca $20 \%$ ) and estuarine waters $(<10 \%)$. This pattern in relation to a eutrophication gradient was also apparent on a seasonal basis, the $<1 \mu \mathrm{m}$ fraction having its maximum significance at times of lowest overall chl a concentration. It is thus suggested that factors limiting growth and accumulation of larger phytoplankton are the primary cause of an increase in the relative significance of picophytoplankton
\end{abstract}

KEY WORDS: Estuary $\cdot$ Picoplankton P Primary production

\section{INTRODUCTION}

The measurement of planktonic primary production is critical to the examination of carbon flow dynamics in the marine environment. Determination of the size distribution of this primary production is also important as it is intimately related to the fate of the carbon fixed, since trophic interactions and sinking rates are sizedependent parameters (Malone 1980, Goldman 1988). Knowledge of the relationship between environmental parameters and phytoplankton size distribution is a vital step towards a comprehensive analysis of the

\footnotetext{
- Present address: Ekologi Laborategia, Zientzi Fakultatea, Euskal Herriko Unibertsitatea (UPV/EHU) PK 644, E-48080 Bilbao, Spain
}

spatio-temporal variability in the community structure of the water column biota.

In recent years particular attention has been paid to the primary productivity of the picoplankton (sensu Sieburth et al. 1978), a size class originally believed to be comprised almost exclusively of heterotrophs (Sorokin 1971), but in the last decade shown to contain a significant photosynthetically active component (Li et al. 1983, Platt et al. 1983, Smith et al. 1985, Joint et al. 1986), i.e. minute chroococcoid cyanobacteria (Johnson \& Sieburth 1979, Waterbury et al. 1979), prochlorophytes (Chisholm et al. 1988) and eukaryotic algae of similar size (Murphy \& Haugen 1985, Kuosa 1988). The photosynthetic picoplankton has been shown to be a major contributor to the overall plankton community primary production rate and chlorophyll a (chl a) bio- 
mass (>50\%) in oligotrophic open ocean tropical and subtropical waters (Gieskes et al. 1979, Platt et al. 1983, Odate \& Maita 1988). This size class, however, has been suggested to be less important in more eutrophic coastal areas (Joint et al. 1986, Søndergaard et al. 1991). Despite the considerable effort made in the last decade with respect to the abundance, metabolic activity and impact of the picophytoplankton in the sea, it is evident that estuarine areas have been as yet little studied in relation to picophytoplankton dynamics, with virtually no information on primary production rate by the $<1 \mu \mathrm{m}$ size fraction.

In the present study we examined the size distribution of chl a biomass and primary production rate and the abundance of picophytoplankton in Southampton Water, a coastal plain estuary on the south coast of England. The spatio-temporal trends of variation of these variables, and hence the influence of environmental parameters (e.g. temperature, nutrients, irradiance) on the size distribution of phytoplankton was to be investigated. For this purpose 2 sampling locations with clearly different physico-chemical conditions were chosen to be representative of the mid and outer estuary.

In open ocean waters, the concentration of phycoerythrin (PE)-containing picocyanobacteria (typically $10^{7}$ cells $1^{-1}$ ) has been claimed to be about an order of magnitude higher than that of eukaryotic picophytoplankton (typically $10^{6}$ cells $1^{-1}$ ) (Murphy \& Haugen 1985), although at times the eukaryotic component has been shown to be dominant (Li \& Wood 1988), It has been suggested that in estuarine waters the biomass of eukaryotic picophytoplankton is frequently more important than that of picocyanobacteria (Sieburth
1984, Ray et al. 1989). In the present study the abundances of both PE-containing picocyanobacteria and eukaryotic picophytoplankton were investigated.

\section{METHODS}

Sampling protocol. Southampton Water is a partially mixed temperate estuary $10 \mathrm{~km}$ long and $2 \mathrm{~km}$ wide with a maximum depth of about $10 \mathrm{~m}$ below mean tide. Sampling was performed at 2 stations, NW Netley buoy, located approximately in the middle of the estuary, $1.5 \mathrm{~km}$ southeast of the confluence of the Test and Itchen river estuaries, and Calshot Spit buoy, situated at the mouth of Southampton Water $(8 \mathrm{~km}$ southeast of NW Netley) (Fig. 1). Sampling took place from January to October 1990 at high water, taking advantage of the unusual tidal regime in this estuary, i.e. a double high water separated by a young flood stand of about $2 \mathrm{~h}$.

At each station vertical profiles of temperature and salinity were obtained using an in-house built digital thermo-salinometer (model MK 1), and Secchi disk depths were also recorded. The latter were converted to extinction coefficients according to Pilgrim (1987).

Water samples were collected with a 2 l Van Dorn bottle at 3 depths $(1,4$ and $6 \mathrm{~m}$ at NW Netley and 1,4 and $8 \mathrm{~m}$ at Calshot Spit), and the water from the 3 depths at each station was combined. From the composite sample $100 \mathrm{ml}$ was preserved in $1 \%$ glutaraldehyde for photosynthetic picoplankton cell counts. Further duplicate subsamples of 100 to $300 \mathrm{ml}$ were filtered serially through $3 \mu \mathrm{m}$ (occasionally $5 \mu \mathrm{m}$ ), $1 \mu \mathrm{m}$ and $0.2 \mu \mathrm{m}$ polycarbonate Nuclepore filters $(47 \mathrm{~mm}$ diameter) for size-fractionated chl a analysis. A filtra-

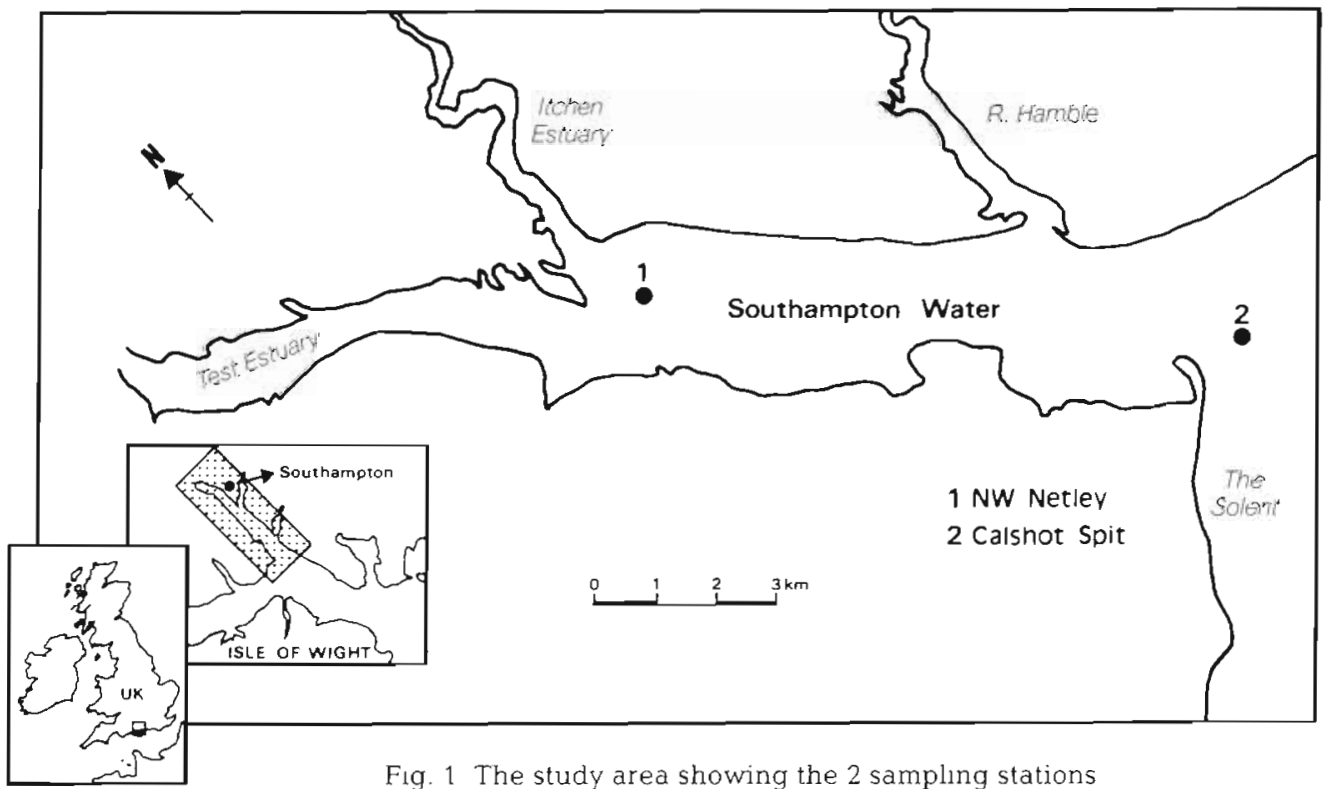

Fig. 1 The study area showing the 2 sampling stations 
tion vacuum of $<2 \mathrm{~cm} \mathrm{Hg}$ was used for the 3 and $1 \mu \mathrm{m}$ filters and of $<15 \mathrm{~cm} \mathrm{Hg}$ for the $0.2 \mu \mathrm{m}$ filters. A further $100 \mathrm{ml}$ subsample was filtered through a glass fiber GF/F filter for total chl a analysis and the filtrate was kept frozen at $-20^{\circ} \mathrm{C}$ for later nitrate plus nitrite and phosphate analysis. Subsamples were also taken for size-fractionated carbon uptake rate determination: duplicate subsamples were incubated with ${ }^{14} \mathrm{C}$-bicarbonate for periods of $4 \mathrm{~h}$ in $125 \mathrm{ml}$ Pyrex bottles at each of 6 irradiance levels $(100,58,28,19,10,5.2 \%$ surface incident solar irradiance) in on-deck type incubators. Seawater was continuously pumped through the incubators to maintain temperature at an in situ value. Incident irradiance was continuously recorded throughout the incubation period using a Kipp and Zonen solarimeter attached to a chart recorder. Occasionally measurements were made with a Macam radiometer/photometer and the solarimeter and the Macam sensor were intercalibrated. Data on total daily incident solar irradiance in the region for the whole year (1990) was obtained from the Meteorological Office. These were based on values recorded approximately $15 \mathrm{~km}$ west of the sampling area. From the daily solar irradiance data mean surface mixed layer irradiance was calculated according to Sinclair (1978).

Size-fractionated chl a and carbon uptake measurements were carried out from April to October 1990.

Picophytoplankton cell counts. PE-containing picocyanobacteria and eukaryotic picophytoplankton cell counts were performed on $3 \mu \mathrm{m}$ polycarbonate Nuclepore filtrates, using a Zeiss epifluorescence microscope. Orange and red autofluorescent cells retained on $0.2 \mu \mathrm{m}$ polycarbonate Nuclepore filters were counted (not less than 100 cells) in 30 to 100 non-overlapping fields of an eyepiece counting grid. Counts were made within 24 to $30 \mathrm{~h}$ after sampling to avoid fading of autofluorescence.

Chlorophyll a analysis. Chl a was determined fluorometrically in 90\% acetone, overnight extracts, using an Aminco fluorocolorimeter. Values were estimated correcting for phaeopigments, as described in Parsons et al. (1984). The coefficient of variation of the chl $a$ measurements was on average $13.1 \%(\mathrm{SD} \pm 16.2 \%)$.

Nutrient analysis. Nitrate plus nitrite concentration was determined by flow injection analysis (Johnson \& Petty 1983). Phosphate concentration was measured using a colorimetric method as detailed in Parsons et al. (1984). The coefficient of variation of the nitrate plus nitrite and phosphate measurements was on average $0.5 \%$.

Carbon fixation rate. Primary production rate measurements were made using the ${ }^{14} \mathrm{C}$ technique (Steemann Nielsen 1952). ${ }^{14} \mathrm{C}$-sodium bicarbonate was added to each incubation bottle to a final activity of $0.032 \mu \mathrm{Ci} \mathrm{ml} \mathrm{ml}^{-1}$. Fractionation was performed post- incubation by serial filtration through $3 \mu \mathrm{m}$ (occasionally $5 \mu \mathrm{m}), 1 \mu \mathrm{m}$ and $0.2 \mu \mathrm{m}$ polycarbonate Nuclepore filters, and the zero-time blank protocol (Li 1986) was adopted. Radioactivity was measured on a Beckman L.S. 3100 series scintillation counter. Counting efficiency was determined by the external standard channels ratio method. The coefficient of variation of replicate measurements was on average $14.5 \%$ (SD $\pm 13.9 \%$ )

Daily water-column-integrated rates of primary production were estimated as follows. From the light extinction the depths of $100,58,28,10$ and $5.2 \%$ incident irradiance were estimated. To obtain values of whole water-column production the carbon fixation rate at the bottom of the water column was estimated. For this purpose the equation of Platt et al. (1980) including the photoinhibition parameter was fitted to the photosynthesis versus irradiance data as described in Garcia \& Purdie (1992) and from the photosynthetic parameters thus obtained, carbon uptake rate was estimated at the irradiance reaching the bottom of the water column. Total rates of carbon fixation for the experimental incubation period were then integrated with depth down to the bottom of the water column. Daily integrated rates were calculated by multiplying by a factor expressing the ratio between daily available irradiance and irradiance available during the experimental incubation as recommended by $\mathrm{BIO}$ MASS (O'Reilly \& Thomas 1983)

Although fractionation data were only available from April to October, an attempt was made to estimate annual production rates in order to evaluate the percentage contribution of the various fractions to an annual integrated value of carbon fixation rate. Chl a concentration measurements from unfractionated samples showed levels to be very similar during the sampling visits in January, February, March and the first week of April. It was thus assumed that the pre-bloom April value of carbon uptake rate could be taken as representative of winter levels and this value was then adjusted to the monthly mean irradiance level and the number of days in each month to obtain the estimates for the 3 winter months, January, February and March. No chl a values were obtained for the autumn months of November and December; however, previous studies have shown chl a values to be fairly similar from October to December in this estuary (Bryan 1979, Kifle \& Purdie 1993). It was thus assumed that the October value is representative of the late autumn months and monthly rates of carbon uptake were estimated as for the winter values. For the rest of the year most of the measurements were taken approximately every $2 \mathrm{wk}$, and each was considered as representative for that period. The values of carbon uptake rate were then adjusted for the total irradiance over those $2 \mathrm{wk}$ periods. 


\section{RESULTS}

\section{Abiotic parameters}

The mean water column temperature recorded from January to October varied between 8.4 and $20.8^{\circ} \mathrm{C}$, and salinity ranged from 30.8 to $34.8 \mathrm{ppt}$.

Vertical profiles of both salinity and temperature showed the water column to be well mixed at high tide throughout the entire sampling period at Calshot Spit (Fig. 2). At NW Netley, however, a salinity gradient of up to $5.5 \mathrm{ppt}$ in the top $4 \mathrm{~m}$ was consistently found during the winter months, up to the first week of April. Temperature distribution at both stations was rather more homogeneous with depth.

Values of mean surface mixed layer irradiance are presented in Table 1. Riley (1967) suggested phytoplankton require a threshold surface mixed layer irradiance of ca $40 \mathrm{~g} \mathrm{cal} \mathrm{cm}^{-2} \mathrm{~d}^{-1}$ (ca $3.27 \mathrm{E} \mathrm{m}^{-2} \mathrm{~d}^{-1}$ ) for a pronounced increase in growth rate to occur. At Calshot Spit this threshold value was achieved by April (Table 1). At NW Netley, however, because the surface
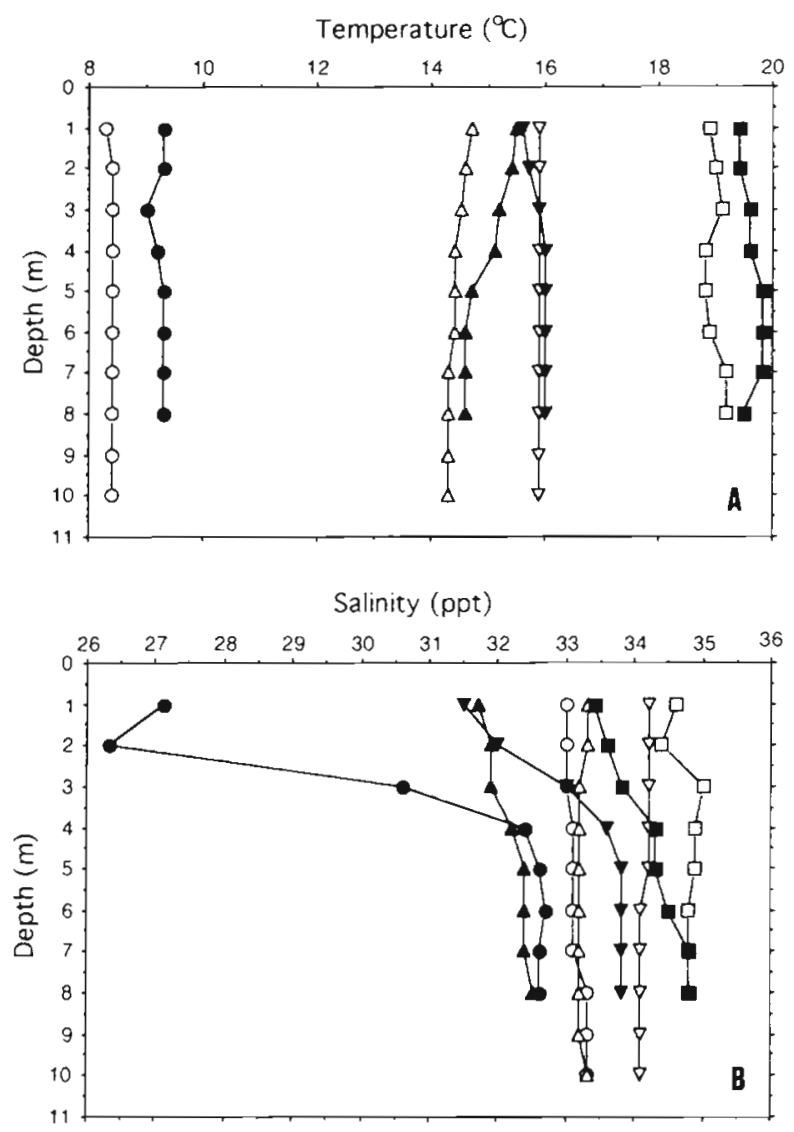

Fig. 2. Typical vertical profiles of (A) temperature and (B) salinity for the various seasons during 1990 at NW Netley:

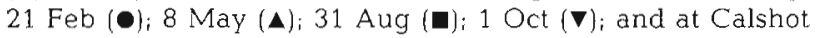
Spit: 24 Jan (0); 8 May ( $\mathbf{\Delta}) ; 31$ Aug (D); 1 Oct ( $\mathbf{\nabla})$
Table 1 Daily total surface incident irradiation $\left(I_{t}\right)$ averaged for each month and daily total irradiation averaged for the surface mixed layer $\left(I_{z m}\right)$ determined as the 2 weekly mean $\left(E \mathrm{~m}^{-2} \mathrm{~d}^{-1}\right)$ at NW Netley and Calshot Spit

\begin{tabular}{|c|c|c|c|}
\hline \multirow[t]{2}{*}{ Month } & \multirow[t]{2}{*}{$I_{\mathrm{t}}$} & \multicolumn{2}{|c|}{$I_{z \mathrm{~m}}$} \\
\hline & & Netley & Calshot \\
\hline \multirow[t]{2}{*}{ January } & 4.83 & nd & nd \\
\hline & & nd & 0.32 \\
\hline \multirow[t]{2}{*}{ February } & 9.66 & nd & $\mathrm{nd}$ \\
\hline & & 3.35 & nd \\
\hline \multirow[t]{2}{*}{ March } & 20.38 & 5.65 & 2.37 \\
\hline & & nd & nd \\
\hline \multirow[t]{2}{*}{ April } & 32.99 & 13.02 & 5.16 \\
\hline & & 12.93 & 10.15 \\
\hline \multirow[t]{2}{*}{ May } & 42.82 & 8.76 & 8.18 \\
\hline & & 9.33 & 8.43 \\
\hline \multirow[t]{2}{*}{ June } & 30.45 & 4.66 & 4.17 \\
\hline & & 5.97 & 6.79 \\
\hline July & 42.33 & $\begin{array}{c}14.65 \\
\end{array}$ & 7.53 \\
\hline \multirow[t]{2}{*}{ August } & 34.71 & 9.99 & 8.27 \\
\hline & & 6.38 & 4.91 \\
\hline \multirow[t]{2}{*}{ September } & 24.64 & nd & nd \\
\hline & & 2.94 & 2.21 \\
\hline \multirow[t]{2}{*}{ October } & 12.44 & 3.19 & 1.96 \\
\hline & & nd & nd \\
\hline \multirow[t]{2}{*}{ November } & 7.45 & nd & nd \\
\hline & & nd & nd \\
\hline \multirow[t]{2}{*}{ December } & 4.66 & nd & nd \\
\hline & & nd & nd \\
\hline nd: not dete & & & \\
\hline
\end{tabular}

mixed layer was shallower than at Calshot Spit during the winter, due to the salinity gradient, irradiance reached a mean value of $3.35 \mathrm{E} \mathrm{m}^{-2} \mathrm{~d}^{-1}\left(41 \mathrm{~g} \mathrm{cal} \mathrm{cm}^{-2}\right.$ $\mathrm{d}^{-1}$ ) in the top $4 \mathrm{~m}$ as soon as the second half of February and was in excess of the critical value (Riley 1967) by the first half of March (Table 1).

Both nitrate plus nitrite and phosphate concentrations showed high winter (nitrate + nitrite 40 to $60 \mu \mathrm{M}$ at NW Netley and 20 to $30 \mu \mathrm{M}$ at Calshot Spit; phosphate: 2 to $12 \mu \mathrm{M}$ at NW Netley and 1 to $5 \mu \mathrm{M}$ at Calshot Spit) and lower summer values (Fig. 3). Minima were recorded during the major phytoplankton bloom events at NW Netley (nitrate + nitrite: ca $2 \mu \mathrm{M}$; phosphate: 0.1 to $0.3 \mu \mathrm{M}$ ). Nutrient concentrations at Calshot Spit were lower than at NW Netley in all samples except during these 2 minima. Nitrate plus nitrite concentration showed some recovery during early summer at NW Netley prior to the Mesodinium rubrum bloom in August. Increases in the phosphate concentration were less pronounced and at Calshot Spit values were lower than $0.5 \mu \mathrm{M}$ until the autumn. The seasonal variations in nutrient levels were similar to those reported by Kifle \& Purdie (1993) at the same 2 stations during 1988 

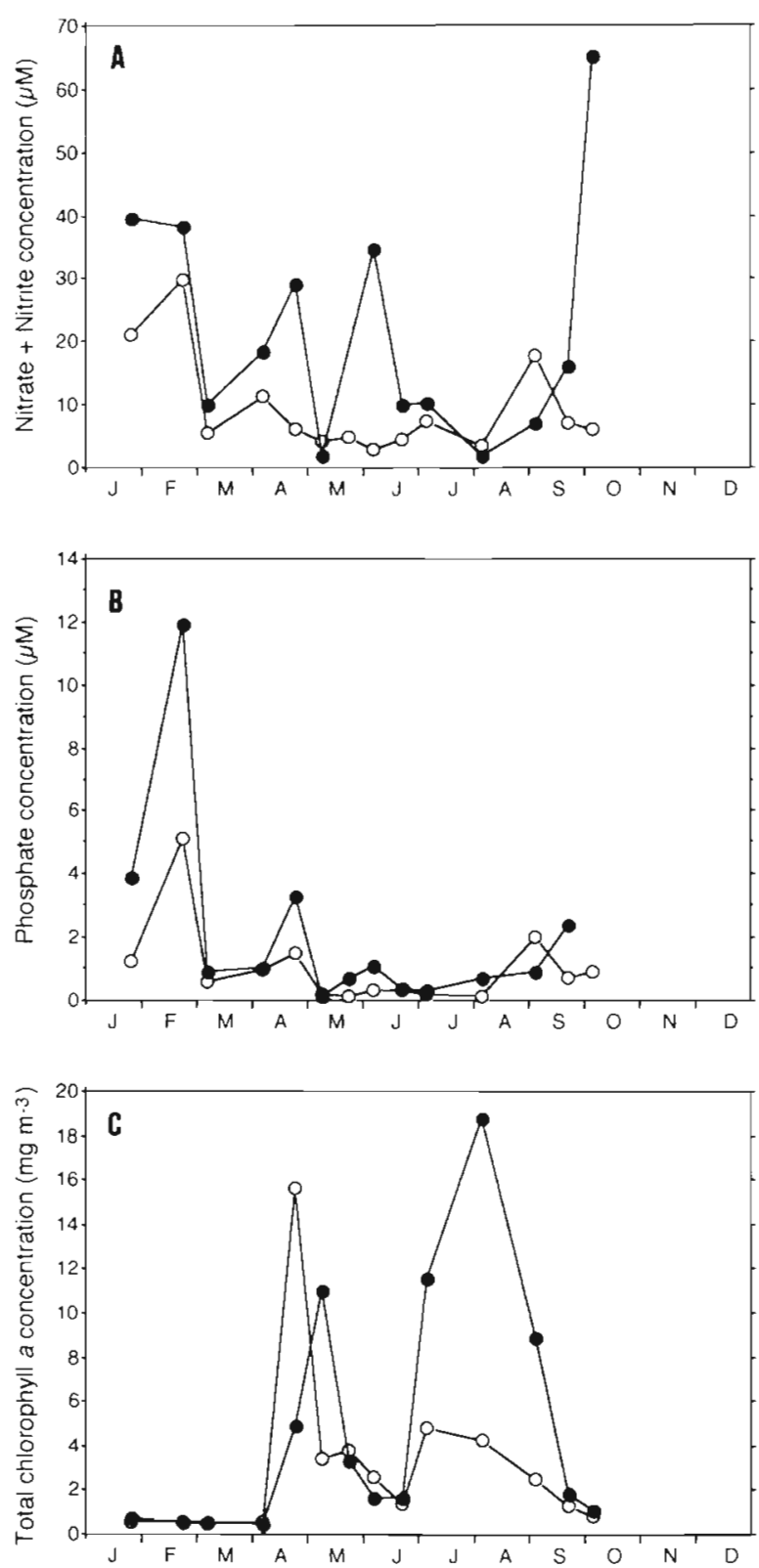

Fig. 3. Temporal distribution of (A) nitrate plus nitrite concentration, (B) phosphate concentration and (C) total plankton community chl a biomass (i.e. unfractionated sample) at NW Netley (1) and Calshot Spit (0)

\section{Chlorophyll a concentration}

At the mouth of the estuary the seasonal distribution of chl a in unfractionated samples showed low winter values followed by a spring peak during the last week of April and intermediate concentrations during summer, dropping to pre-spring bloom levels by October (Fig. 3). The size-fractionated chl a distribution showed this spring peak to be dominated by the $>3 \mu \mathrm{m}$ size fraction (9.72 $\mathrm{mg} \mathrm{m}^{-3}$ ) (Table 2) and microscopic examination revealed the prymnesiophyte algae Phaeocystis sp. and chain-forming diatoms of the genus Chaetoceros to be the dominant phytoplankters (D. Kifle pers. comm.). At NW Netley winter chlorophyll values were also low and the spring peak was not recorded until the first week of May (Fig. 3). This spring peak at NW Netley was also dominated by the $>3 \mu \mathrm{m}$ size fraction (8.69 $\mathrm{mg} \mathrm{m}^{-3}$ ) with Phaeocystis and Chaetoceros as the major contributors. Unlike at Calshot Spit, the chl a concentration exhibited high values during summer at NW Netley, with a maximum of $18 \mathrm{mg} \mathrm{chl} \mathrm{a} \mathrm{m}^{-3}$ recorded on 2 August. This peak of chl a was mainly due to the $>3 \mu \mathrm{m}$ size fraction (Table 2 ) and was dominated by the phycoerythrin-containing phototrophic ciliate Mesodinium rubrum, which was observed to aggregate, forming dense red patches irregularly distributed along the upper-mid estuary.

At NW Netley the chl a concentration corresponding to the $1-3 \mu \mathrm{m}$ fraction exhibited 2 major peaks of about $2 \mathrm{mg} \mathrm{m}^{-3}$, coinciding with the Phaeocystis sp. bloom in May and the Mesodinium peak in August. The unavoidable use of $5 \mu \mathrm{m}$ filters instead of $3 \mu \mathrm{m}$ filters on 2 occasions (22 May and 31 August) may have contributed to the apparent slight increase in chl a concentration observed in this fraction on these dates. Levels of chl a outside the 2 major peaks and when $5 \mu \mathrm{m}$ filters were used were in the range 0.05 to $0.2 \mathrm{mg}$ chl a $\mathrm{m}^{-3}$. The chl a contained in particles passing through $1 \mu \mathrm{m}$ filters was low during late winter and spring $\left(0.04\right.$ to $\left.0.08 \mathrm{mg} \mathrm{chl} \mathrm{a} \mathrm{m}^{-3}\right)$, increasing during the summer (June to September) with a maximum of $0.56 \mathrm{mg} \operatorname{chl~a~} \mathrm{m}^{-3}$ recorded coinciding with the red water event in August.

At Calshot Spit the pattern of variation of the $<1 \mu \mathrm{m}$ fraction was approximately analogous to that at NW Netley, with high values during summer, except that no outstanding peak was recorded in August. For the fraction passing through $3 \mu \mathrm{m}$ filters and retained on

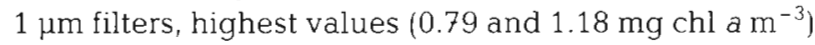
were recorded during the 2 sampling visits in May. In summer, concentrations of about $0.5 \mathrm{mg} \mathrm{chl} \mathrm{a} \mathrm{m}^{-3}$ were measured during August, coinciding with the use of $5 \mu \mathrm{m}$ filters. For the rest of the sampling period con-

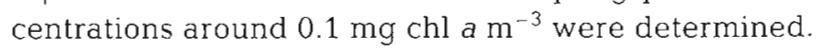

The comparison of total chl a determined by summing up the various fractions and by whole sample filtration onto $\mathrm{GF} / \mathrm{F}$ filters yielded an average deviation of $16 \%(\mathrm{SD} \pm 12 \%)$.

The temporal variation of the contribution by each fraction to the phytoplankton community chl a concentration is shown in Table 2 . The chl a retained by $3 \mu \mathrm{m}$ filters was the dominant fraction throughout the entire period of study, both at NW Netley [72.3 to $95.9 \%$ of the sum of fractions, mean $85.7 \%(S D \pm 7.7)]$ and at 
Table 2. Temporal variation of size-fractionated chl a biomass $\left(\mathrm{mg} \mathrm{m}^{-3}\right)$ at $\mathrm{NW}$ Netley and Calshot Spit. The percentage contribution by the various size fractions to total plankton community chl a concentration (sum of fractions) is given in parenthesis

\begin{tabular}{|c|c|c|c|c|c|c|}
\hline $\begin{array}{c}\text { Date } \\
(1990)\end{array}$ & $>3 \mu \mathrm{m}$ & $\begin{array}{c}\text { NW Netley } \\
1-3 \mu \mathrm{m}\end{array}$ & $<1 \mu \mathrm{m}$ & $>3 \mu \mathrm{m}$ & $\begin{array}{c}\text { Calshot Spit } \\
1-3 \mu \mathrm{m}\end{array}$ & $<1 \mu \mathrm{m}$ \\
\hline $5 \mathrm{Apr}$ & $0.35(79.4)$ & $0.05(12.2)$ & $0.04 \quad(8.4)$ & $0.66(82.9)$ & $0.09(11.3)$ & $0.05(5.8)$ \\
\hline $23 \mathrm{Apr}$ & $3.72 \quad(95.9)$ & $0.12 \quad(3.1)$ & $0.04 \quad(1.0)$ & $9.72(97.9)$ & $0.13 \quad(1.3)$ & $0.08(0.8)$ \\
\hline 8 May & $8.69(79.8)$ & $2.13(19.5)$ & $0.08(0.7)$ & $2.37\{73.2\}$ & $0.79(24.4)$ & $0.08 \quad(2.4)$ \\
\hline $22 \mathrm{May}^{d}$ & $2.30(84.6)$ & $0.39(14.4)$ & $0.03(1.0)$ & $1.19(48.6)$ & $1.18(48.3)$ & $0.08 \quad(3.1)$ \\
\hline 4 Jun & $1.15(82.4)$ & $0.11 \quad(7.8)$ & $0.14(9.8)$ & $1.83\{90.1\}$ & 0.10 & $0.09(4.7)$ \\
\hline $20 \mathrm{Jun}$ & 1.34 (84.1) & $0.12 \quad(7.8)$ & $0.13(8.1)$ & $0.99(81.5)$ & $0.13(10.4)$ & $0.10(8.1)$ \\
\hline $3 \mathrm{Jul}$ & $8.79(96.4)$ & $0.20 \quad(2.2)$ & $0.13(1.4)$ & $3.98(92.9)$ & 0.16 & $0.14 \quad(3.3)$ \\
\hline 2 Aug & $7.04 \quad(72.3)$ & $2.14(21.9)$ & $0.56 \quad(5.8)$ & $2.58 \quad(80.6)$ & $0.46 \quad(14.3)$ & $0.16 \quad(5.1)$ \\
\hline 31 Aug $^{a}$ & $7.50 \quad(92.8)$ & $0.38 \quad(4.7)$ & $0.20(2.5)$ & $1.90(75.0)$ & $0.51(20.0)$ & $0.13(5.0)$ \\
\hline 18 Sep & $1.56(92.5)$ & $0.05 \quad(3.1)$ & $0.07 \quad(4.4\}$ & $1.07(91.0)$ & $0.05 \quad(4.5)$ & 0.05 (4.5) \\
\hline $1 \mathrm{Oct}$ & $0.90(82.9)$ & $0.08 \quad(7.8)$ & $0.10(9.3)$ & $0.88(84.6)$ & $0.09 \quad(8.7)$ & $0.07(6.7)$ \\
\hline
\end{tabular}

Calshot Spit [48.6 to $97.9 \%$, mean $81.7 \%(\mathrm{SD} \pm 13.3)]$ The second most prominent fraction appeared to be the 1-3 $\mu \mathrm{m}$ fraction, for which percentages in the range 3.1 to $21.9 \%$ [mean $9.5 \%(\mathrm{SD} \pm 6.7)$ ] at NW Netley and 1.3 to $48.3 \%$ [mean $13.8 \%$ (SD \pm 13.4 )] at Calshot Spit were recorded. The least significant fraction was the $<1 \mu \mathrm{m}$, with percentage contributions in the range 0.7 to $9.8 \%$ [mean $4.8 \%(\mathrm{SD} \pm 3.6)$ ] at NW Netley and 0.8 to $8.1 \%$ [mean $4.5 \%(\mathrm{SD} \pm 4.5)]$ at Calshot Spit.

The seasonal variation of the percentage contribution to the whole sample chl a concentration showed the $<1 \mu \mathrm{m}$ fraction to be least significant during the spring blooms at both stations with a tendency to become more prominent during winter and autumn and also during periods of lowest overall chl a biomass in summer, i.e. during June, at NW Netley. At Calshot Spit differences between autumn/winter and summer were not as marked. In the 1-3 $\mu \mathrm{m}$ fraction the percentage contribution varied in much the same way as the actual concentration of chl a for both stations.

A plot of the percentage contribution by the $<1 \mu \mathrm{m}$ fraction against the total (sum of fractions) chl a concentration (Fig, 4) suggested an inverse exponential relationship.

\section{Carbon fixation rates}

Size-fractionated carbon fixation rates and the percentage contributions of each size fraction to the total are presented in Table 3. At NW Netley, rates ranged

Table 3. Temporal variation of size-fractionated depth-integrated daily rates of carbon fixation rate $\left(g \mathrm{C} \mathrm{m}^{-2} \mathrm{~d}^{-1}\right)$ at NW Netley and Calshot Spit. The percentage contribution by the various size fractions is given in parenthesis

\begin{tabular}{|c|c|c|c|c|c|c|}
\hline \multirow{3}{*}{$\begin{array}{c}\begin{array}{c}\text { Date } \\
(1990)\end{array} \\
5 \mathrm{Apr}\end{array}$} & \multicolumn{3}{|c|}{ NW Netley } & \multicolumn{3}{|c|}{ Calshot Spit } \\
\hline & $>3 \mu \mathrm{m}$ & $1-3 \mu \mathrm{m}$ & $<1 \mu \mathrm{m}$ & $>3 \mu \mathrm{m}$ & $1-3 \mu \mathrm{m}$ & $<1 \mu \mathrm{m}$ \\
\hline & $0.066(68.8)$ & $0.017(17.7)$ & $0.013(13.5)$ & $0.171 \quad(84.6)$ & $0.024 \quad(11.9)$ & $0.007 \quad$ (3.5) \\
\hline $23 \mathrm{Apr}$ & $0.837(92.5)$ & $0.042 \quad(4.6)$ & $0.026 \quad(2.9)$ & $2.131 \quad(96.5)$ & $0.046 \quad(2.1)$ & $0.030 \quad(1.4)$ \\
\hline $8 \mathrm{May}$ & $0.841(84.4)$ & $0.095 \quad(9.6)$ & $0.060 \quad(6.0)$ & $0.526(86.2)$ & $0.061(10.0)$ & $0.023 \quad(3.8)$ \\
\hline 22 May" $^{\prime \prime}$ & $0.553(80.6)$ & $0.099(14.4)$ & $0.034 \quad\{5.0\}$ & $0.745(66.6)$ & $0.307(27.5)$ & $0.066 \quad\{5.9\}$ \\
\hline 4. Jun & $0.350 \quad(82.9)$ & $0030 \quad(7.1)$ & $0.042(10.0)$ & 0.640 (88.0) & $0.046 \quad(6.3)$ & $0.041 \quad(5.7)$ \\
\hline $20 \mathrm{Jun}$ & $0.237(81.4)$ & $0.021 \quad(7.2)$ & $0.033(11.4)$ & $0.317(75.9)$ & $0.058(12.8)$ & 0.051 (11.3) \\
\hline 3 Jul & $1.172(92.9)$ & 0.036 & 0.054 & $0.693(87.0)$ & $0.043 \quad(5.4)$ & $0.061 \quad(7.6)$ \\
\hline 2 Aug $^{d}$ & $2.145(61.7)$ & $1.062(30.5)$ & $0.273 \quad(7.8)$ & $0.664 \quad(68.9)$ & $0.181(18.8)$ & $0.119(12.3)$ \\
\hline $31 \mathrm{Aug}^{\mathrm{a}}$ & $1.712(87.8)$ & $0.146 \quad(7.5)$ & 0.092 & $0.386(69.2)$ & $0.104(18.6)$ & $0.068 \quad(12.2)$ \\
\hline $18 \mathrm{Sep}$ & $0.084(79.2)$ & 0.010 & $0.012(11.3)$ & $0.068(81.0)$ & $0.010(11.9)$ & $0.006 \quad(7.1)$ \\
\hline 1 Oct & nd $(67.0)$ & nd $(18.4)$ & nd $(14.6)$ & nd $(75.6)$ & nd $(18.7)$ & nd $\quad(5.7)$ \\
\hline
\end{tabular}




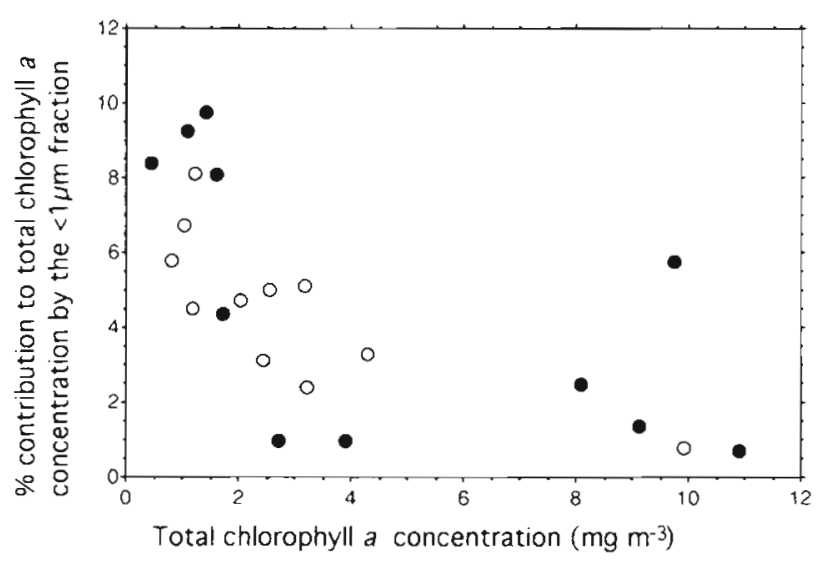

Fig. 4. Relationship between the chl a concentration, expressed as a percentage of the sum of fractions, in the $<1 \mu \mathrm{m}$ size fraction and the total chl $a$ biomass (sum of fractions) in samples from NW Netley (-) and Calshot Spit (o)

from 0.066 to $2.145 \mathrm{~g} \mathrm{C} \mathrm{m}^{-2} \mathrm{~d}^{-1}$ for the fraction retained on $3 \mu \mathrm{m}$ filters, from 0.010 to $1.062 \mathrm{~g} \mathrm{C} \mathrm{m}^{-2}$ $\mathrm{d}^{-1}$ for the $1-3 \mu \mathrm{m}$ fraction and from 0.012 to $0.273 \mathrm{~g} \mathrm{C}$ $\mathrm{m}^{-2} \mathrm{~d}^{-1}$ for the $<1 \mu \mathrm{m}$ fraction. At Calshot Spit rates varied from 0.068 to $2.131 \mathrm{~g} \mathrm{C} \mathrm{m}^{-2} \mathrm{~d}^{-1}$ for the $>3 \mu \mathrm{m}$ fraction, from 0.010 to $0.307 \mathrm{~g} \mathrm{C} \mathrm{m}^{-2} \mathrm{~d}^{-1}$ for the $1-3 \mu \mathrm{m}$ fraction and from 0.006 to $0.119 \mathrm{~g} \mathrm{C} \mathrm{m}^{-2} \mathrm{~d}^{-1}$ for the $<1 \mu \mathrm{m}$ fraction.

It was observed that the $1-3$ and the $<1 \mu \mathrm{m}$ fractions made, in general, a higher contribution to carbon uptake rate than to chl a concentration (i.e. the majority of values are above the $x=y$ line in Fig. 5B, C). The reverse was the case for the $>3 \mu \mathrm{m}$ fraction (Fig. 5A).

The estimates of monthly carbon uptake rates (sum of fractions) showed August to be the most productive month at the mid estuary station; in contrast, at the outer station April was the most productive month. The total annual rate of carbon uptake (sum of fractions) was estimated to be 177 and $130 \mathrm{~g} \mathrm{C} \mathrm{m}^{-2} \mathrm{yr}^{-1}$ for NW Netley and Calshot Spit respectively (Table 4). The distribution by fractions of the annual rate of carbon uptake was similar at both stations and showed the $>3 \mu \mathrm{m}$ fraction to account for 80.7 and $82.8 \%$ at NW Netley and Calshot Spit, respectively, the $1-3 \mu \mathrm{m}$ fraction to contribute to 13.1 and $10.9 \%$ at NW Netley and Calshot Spit, respectively, and the $<1 \mu \mathrm{m}$ fraction to represent 6.2 and $6.3 \%$ at NW Netley and Calshot Spit, respectively (Table 4). A distribution by fractions for each season is presented in Table 5. It is apparent that the $>3 \mu \mathrm{m}$ fraction was dominant in all seasons $(>65 \%)$. The maximum contribution from this fraction was determined in spring ( 85.1 and $85.8 \%$ at NW Netley and Calshot Spit, respectively). For the 1-3 $\mu \mathrm{m}$ fraction the lowest contribution was measured in spring (8.9 and $10.2 \%$ at NW Netley and Calshot Spit,
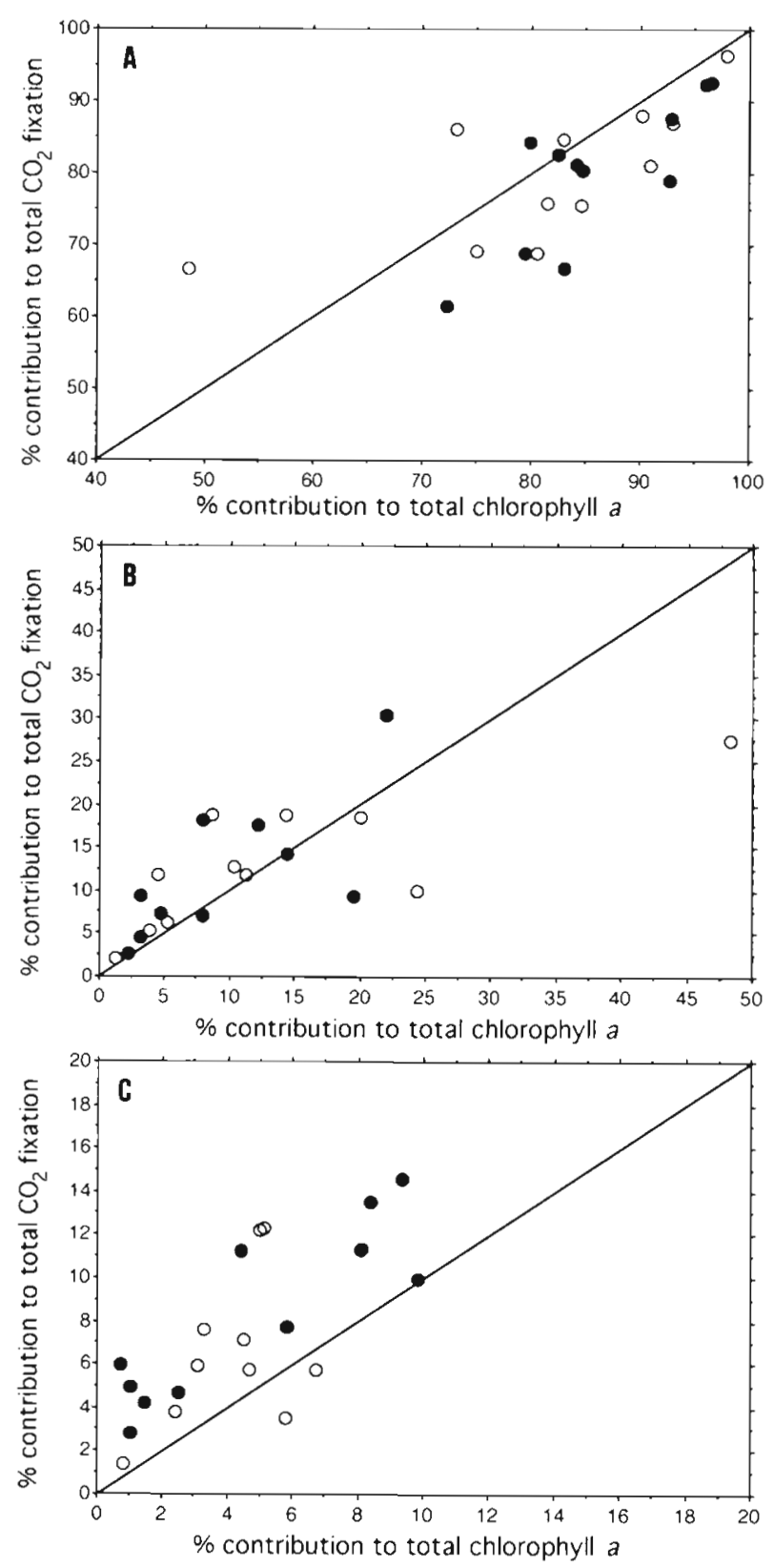

Fig. 5. Relationship between the percentage contribution to the total depth-integrated daily rate of carbon fixation (i.e. sum of fractions) and to the total chl a biomass (sum of fractions) for (A) the $>3 \mu \mathrm{m}$ (B) the $1-3 \mu \mathrm{m}$ and (C) the $<1 \mu \mathrm{m}$ size fractions, as determined from samples collected at NW Netley

(•) and Calshot Spit (O)

respectively) and maximum values were estimated in autumn and winter (up to $18.7 \%$ ). At NW Netley, autumn and winter were the periods when the $<1 \mu \mathrm{m}$ fraction was most significant (>10\%). At Calshot Spit, however, summer appeared to be the season when the $<1 \mu \mathrm{m}$ fraction made the most significant contribution $(9.4 \%)$. The distribution by seasons of the annual rate 
Table 4. Carbon fixation rate $\left(\mathrm{gC} \mathrm{m}^{-2}\right)$ by the various size fractions and by the total plankton community integrated for the seasons at NW Netley and Calshot Spit

\begin{tabular}{|lcrrrrrrr}
\hline & \multicolumn{4}{c}{ NW Netley } & \multicolumn{3}{c}{ Calshot Spit } \\
& Total (\%) & $>3 \mu \mathrm{m}$ & $1-3 \mu \mathrm{m}$ & $<1 \mu \mathrm{m}$ & Total (\%) & $>3 \mu \mathrm{m}$ & $1-3 \mu \mathrm{m}$ & $<1 \mu \mathrm{m}$ \\
\hline Winter (Jan-Mar) & $2.5(1.4)$ & 1.7 & 0.4 & 0.3 & $5.2(4.0)$ & 4.4 & 0.6 \\
Spring (Apr-Jun) & $43.2(24.4)$ & 36.7 & 3.8 & 2.6 & $67.6(51.8)$ & 58.0 & 6.9 & 0.2 \\
Summer (Jul-Sep) & $126.3(71.5)$ & 100.7 & 18.0 & 7.5 & $54.2(41.5)$ & 43.1 & 6.0 & 5.1 \\
Autumn (Oct-Dec) & $4.7(2.7)$ & 3.4 & 0.9 & 0.5 & $3.5(2.7)$ & 2.6 & 0.6 & 0.2 \\
Annual (\%) & & 80.7 & 13.1 & 6.2 & & 82.8 & 10.9 & 6.3 \\
\hline
\end{tabular}

Table 5. Percent distribution by (A) fractions for each season and (B) by seasons for each fraction of the total carbon fixation rate at NW Netley and CaIshot Spit

\begin{tabular}{|c|c|c|c|c|c|c|c|c|c|c|c|c|}
\hline & \multicolumn{6}{|c|}{ NW Netley } & \multicolumn{6}{|c|}{ Calshot Spit } \\
\hline & \multicolumn{2}{|c|}{$>3 \mu \mathrm{m}$} & \multicolumn{2}{|c|}{$1-3 \mu \mathrm{m}$} & \multicolumn{2}{|c|}{$<1 \mu \mathrm{m}$} & \multicolumn{2}{|c|}{$>3 \mu \mathrm{m}$} & \multicolumn{2}{|c|}{$1-3 \mu \mathrm{m}$} & \multicolumn{2}{|c|}{$<1 \mu \mathrm{m}$} \\
\hline & A & B & A & $\mathrm{B}$ & A & B & $A$ & $B$ & A & $\mathrm{B}$ & $\mathrm{A}$ & $\mathrm{B}$ \\
\hline Winter (Jan-Mar) & 68.8 & 1.2 & 17.7 & 1.9 & 13.5 & 3.1 & 84.6 & 4.1 & 11.9 & 4.4 & 3.5 & 2.3 \\
\hline Spring (Apr-Jun) & 85.1 & 25.8 & 8.9 & 16.7 & 6.0 & 23.5 & 85.8 & 53.6 & 10.2 & 48.5 & 4.0 & 33.3 \\
\hline Summer (Jul-Sep) & 79.8 & 70.6 & 14.2 & 77.6 & 6.0 & 69.0 & 79.4 & 39.8 & 11.2 & 42.5 & 9.4 & 62.0 \\
\hline Autumn (Oct-Dec) & 71.4 & 2.4 & 18.5 & 3.8 & 10.1 & 4.4 & 75.6 & 2.5 & 18.7 & 4.6 & 5.7 & 2.4 \\
\hline
\end{tabular}

of carbon uptake for each fraction is also presented in Table 5. At NW Netley similar trends were observed for all fractions, summer being the most productive season $(>68 \%)$ and winter being the least productive $(<4 \%)$. At Calshot Spit, however, for the $>3 \mu \mathrm{m}$ fraction the bulk of the production occurred in spring $(53.6 \%)$; for the $1-3 \mu \mathrm{m}$ fraction spring and summer shared similar proportions and for the $<1 \mu \mathrm{m}$ fraction, as at NW Netley, summer was the most productive season $(62.0 \%)$.

\section{Picophytoplankton: phycoerythrin-containing} picocyanobacteria and eukaryotic picophytoplankton

PE-containing chroococcoid cyanobacteria cell numbers varied from $2 \times 10^{4}$ to $1.3 \times 10^{7}$ cells l $^{-1}$ at the 2 stations in the estuary. The seasonal distribution showed a distinct peak during midsummer at both stations (Fig. 6B). At Calshot Spit the PE-containing picocyanobacteria were maintained at high concentrations for a longer period (sampling dates from late June to August) than at NW Netley (sampling date in July). PE-containing picocyanobacteria and temperature were significantly correlated, but the correlation was not very strong $\left[r^{2}=0.487\right.$ for $N W$ Netley and $r^{2}=0.331$ for Calshot Spit $(p<0.05)]$. There was no positive significant correlation between $\mathrm{PE}$-containing picocyanobacteria cell density and nitrate plus nitrite or phosphate concentration. PE-containing picocyanobacteria
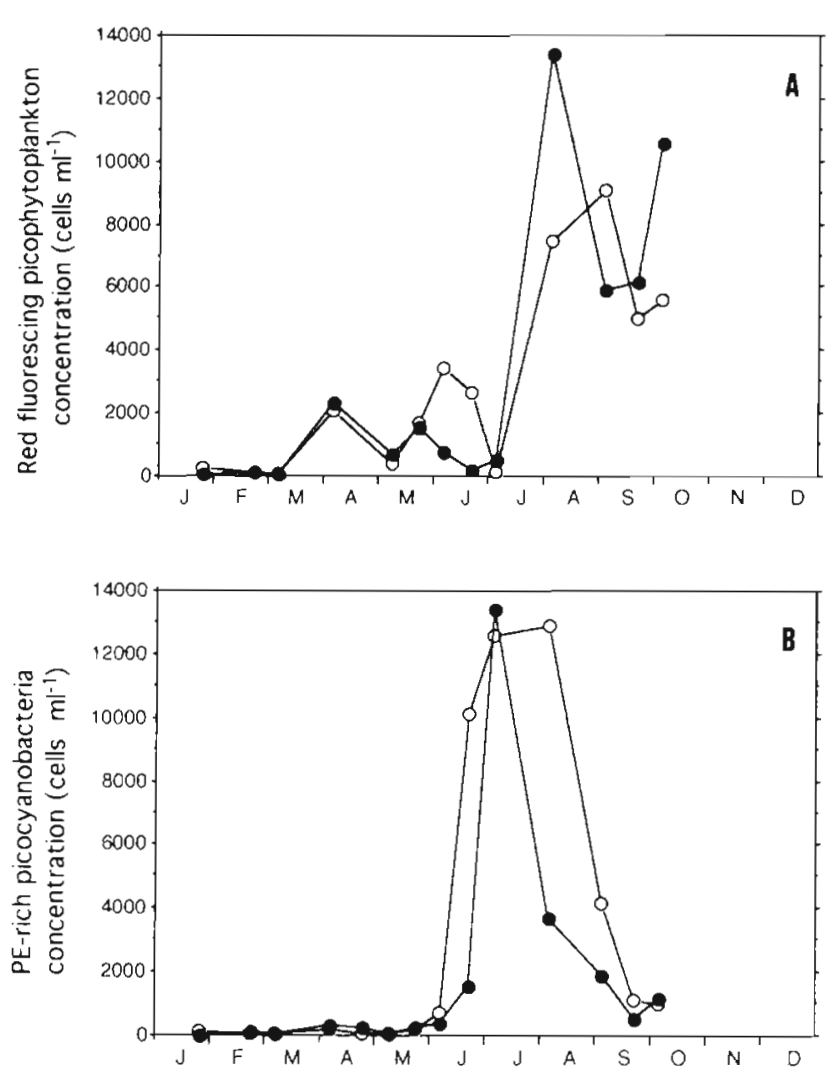

Fig. 6. Temporal distribution of (A) eukaryotic picophytoplankton and (B) PE-containing picocyanobacteria cell numbers at NW Netley (-) and Calshot Spit (O) 
cell numbers were significantly correlated between stations $\left(r^{2}=0.561, p<0.01\right)$.

Concentrations of eukaryotic algal cells passing through $3 \mu \mathrm{m}$ filters ranged from $8 \times 10^{4}$ to $1.3 \times 10^{7}$ cells $\mathrm{l}^{-1}$ (Fig. 6A). An outstanding peak of $<3 \mu \mathrm{m}$ eukaryotic cells was observed in May, coinciding with the bloom of Phaeocystis. These cells cannot be considered as true picophytoplankters, however, since the vast majority were cells of Phaeocystis liberated from disrupted colonies, and this value has not been included in Fig. 6A. Peaks of 'true' eukaryotic picophytoplankters were recorded in August: $1.3 \times 10^{7}$ and

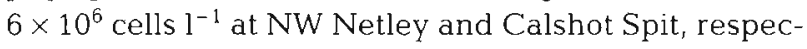
tively. From June to October the eukaryotic picophytoplankton population was dominated by minute forms, ca $1 \mu \mathrm{m}$ in diameter. The seasonal trend of variation was very similar at both stations and there was a high correlation between eukaryotic picophytoplankton at NW Netley and Calshot Spit $\left(\mathrm{r}^{2}=0.632, \mathrm{p}<0.001\right)$. Similar to the PE-containing picocyanobacteria, the eukaryotic picophytoplankton cell density showed no positive significant correlation with nitrate plus nitrite or phosphate concentration.

\section{DISCUSSION}

\section{Methodology}

For the discrimination of size-specific rates of activity and biomass indicators (e.g. chl $a_{\text {, particulate organic }}$ carbon, ATP) physical fractionation by differential filtration is the most widely used method. Despite its simplicity and widespread use, precise control of the filtration technique is difficult, since the effectiveness of the size separation is influenced by a variety of factors, such as the filter type, vacuum and characteristics of the particles in the sample (e.g. cellular shape, fragility and flexibility of cells and particle density). In the present study conducted in Southampton Water, during the colonial Phaeocystis bloom in May, colony disruption is likely to have occurred during filtration, since passage of some cells through $3 \mu \mathrm{m}$ pore sized filters was apparent. Thus the cell number and chl a concentration measurements included some of these cells as part of the 1-3 $\mu \mathrm{m}$ fraction. Size-fractionated carbon uptake measurements may also include inaccuracies, since colonial Phaeocystis accumulates an appreciable amount of its organic carbon in the colony matrix (Lancelot et al. 1986), and if the colonies are disrupted, the mucilaginous substances of the matrix solubilize, passing through the filters and giving spuriously large values of excretion rate (Lancelot 1983).

During the summer the presence of Mesodinium rubrum (ca $40 \mu \mathrm{m}$ in diameter; D. Kifle pers. comm.) also posed some interpretative difficulties. The ciliate is well known for its extreme fragility (Lindholm 1985) and there is evidence for cell rupture during incubation in bottles and during filtration (Throndsen 1978, Smith \& Barber 1979). It is likely that cell fragments of this organism may have caused some overestimation of chl $a$ in the 2 smallest fractions. However, the high chl a concentration will have caused some clogging of the filter and may have partly neutralized this effect. These effects are hardly quantifiable (Jochem 1989) and some caution should be exercised in the interpretation of the results.

Despite these fractionation difficulties, the seasonal variation of carbon fixation rate in the $<3 \mu \mathrm{m}$ size fraction [i.e. sum of $1-3(5) \mu \mathrm{m}+<1 \mu \mathrm{m}$ fractions] in general terms followed the succession observed in total picophytoplankton (i.e. PE-rich picocyanobacteria + eukaryotic picophytoplankton) cell numbers (Fig. 7). As we can see from Fig. 7, the slight discrepancies in magnitude were mainly observed during the Phaecystis bloom in May at Calshot Spit and during the Mesodinium rubrum bloom in July at NW Netley. The seasonal distribution of size-fractionated carbon fixation rate, in turn, closely followed the changes in sizefractionated chl a concentration.

Additionally it should be noted that the use of a 3depth combined sample (adopted in view of logistic limitations) provides information which can be considered as an average representation of the water column. However, it does not account for the possible differences in the size distribution of phytoplankton at different depths. The protocol adopted is less likely to have affected the results obtained in samples from Calshot Spit, however, as at this station the water column was well mixed throughout the entire sampling period, but introduces some uncertainty in relation to measurements made in samples from NW Netley at times when the water column was stratified.

\section{Photosynthetic picoplankton}

In the marine environment PE-containing chroococcoid cyanobacteria are typically reported in concentrations of the order of $10^{7}$ cells $^{-1}$ (Platt et al. 1983, Murphy \& Haugen 1985, Glover et al. 1986). In coastal and inshore areas seasonal peaks generally attain $10^{8}$ cells $1^{-1}$ (El Hag \& Fogg 1986, Shapiro \& Haugen 1988, Hargraves et al. 1989). Levels of PE-containing picocyanobacteria recorded in Southampton Water were within the range generally reported in the marine environment, but peaks of only $1.5 \times 10^{7}$ cells $^{-1}$ were reached in the summer. Low summer maxima of $4 \times 10^{7}$ cells $\mathrm{l}^{-1}$ and around $2 \times 10^{7}$ cells $\mathrm{l}^{-1}$ have also been measured in Funka Bay (Japan) and in a Chesapeake 

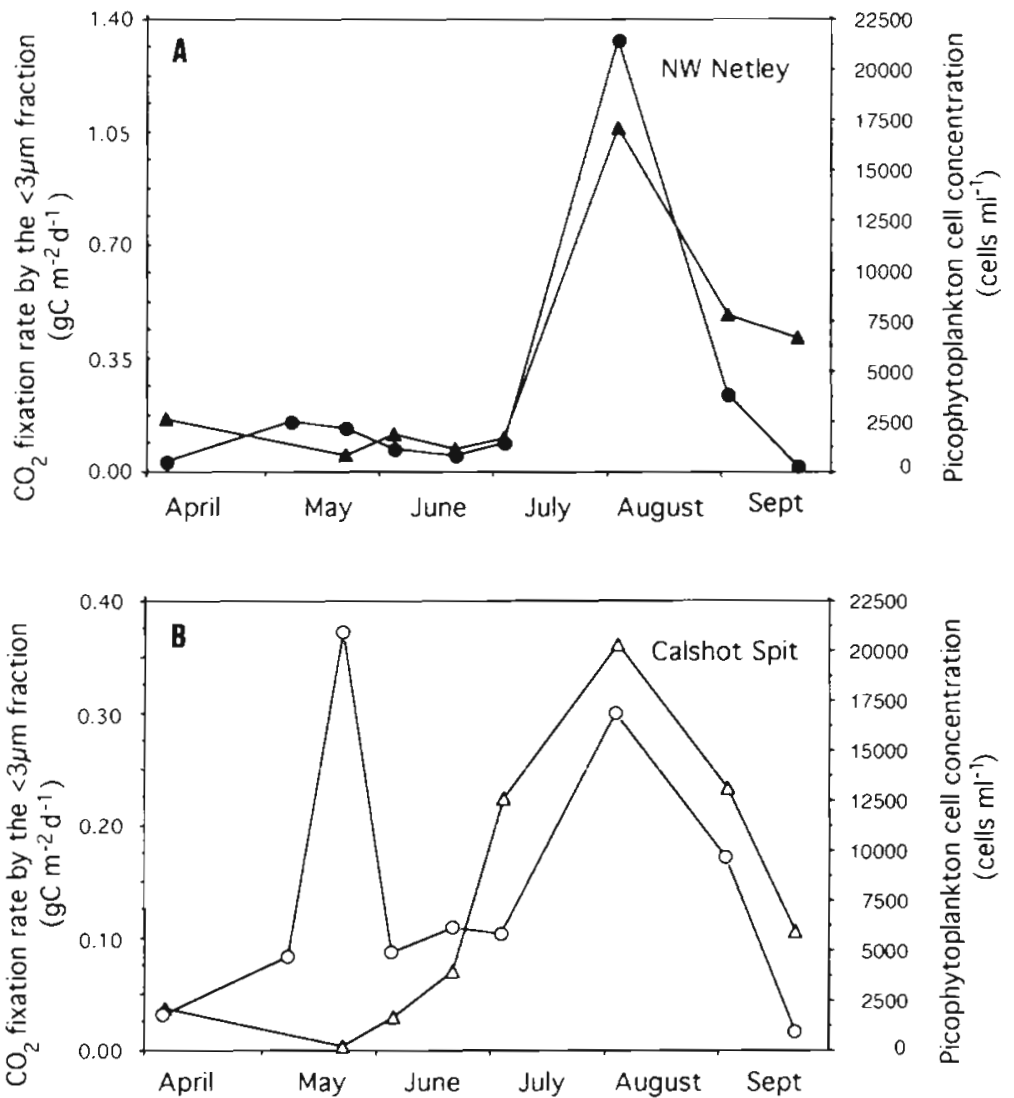

Fig. 7. Relationship between $\mathrm{CO}_{2}$ fixation rate by the $<3 \mu \mathrm{m}$ size fraction [i.e. $<1 \mu m+1-3(5) \mu m$ size fractions] $(\bullet, 0)$ and total picophytoplankton (i.e. PE-rich picocyanobacteria + eukaryotic picophytoplankton) cell number $(\Delta, \Delta)$ at $(A)$ NW Netley and (B) Calshot Spit

Bay sub-estuary (USA), respectively (Odate 1989, Ray et al. 1989).

Although data on eukaryotic picophytoplankton abundance are scant in the literature, $10^{6}$ cells $l^{-1}$ has been suggested as a typical cell density (Murphy \& Haugen 1985, Kuosa 1988). However, in coastal and estuarine waters sporadic blooms of greater magnitude (up to $10^{9}$ cells $1^{-1}$ ) are not uncommon (Wilhelm et al. 1982, Hargraves et al. 1989). In agreement with observations in other studies in estuarine areas (Sieburth 1984, Ray et al. 1989) eukaryotic picophytoplankton biomass was at times larger than that of picocyanobacteria, a pattern which has also been observed in oceanic waters (Li \& Wood 1988), but which does not conform with the typical conditions found in these waters (Murphy \& Haugen 1985).

Prochlorophytes were not enumerated in the present study. However, although there is virtually no information on their impact in estuarine waters, they have been shown to be a very minor component of the photosynthetic picoplankton in coastal waters (Selmer et al. 1993).
The seasonal peak of abundance of PEcontaining picocyanobacteria recorded during a warm summer month appears as a generalized pattern in temperate regions (El Hag \& Fogg 1986, Waterbury et al. 1986, Jochem 1988, Odate 1989). The seasonal distribution of eukaryotic picophytoplankton is less well documented. In agreement with the present results, picophytoplankton other than PE-containing picocyanobacteria were found to reach an annual maximum of abundance in late summer in Funka Bay (Odate 1989). In contrast, Kuosa (1991) observed no clear seasonal pattern in the Baltic Sea.

In temperate coastal areas the contribution of picoplankton to the annual primary production rate in the water column is estimated to be about 20 to $30 \%$ (Larsson \& Hagström 1982, Joint et al. 1986, Maita $\&$ Odate 1988). The contribution of picoplankton in these waters has been reported to increase during summer to values up to between 40 and 60\% (Larsson \& Hagström 1982, Maita \& Odate 1988). There are few reports from estuarine areas, but their relative productive importance seems to be somewhat lower than in coastal areas and values around 10\% have been reported for the $<3 \mu$ m size fraction (Jochem 1989, Madariaga \& Orive 1989. Ray et al. 1989), although these studies include measurements for different periods of the year and thus estimates are not strictly intercomparable. In the present study values of around 17 to $20 \%$ for the $<3 \mu \mathrm{m}$ fraction and $6 \%$ for the $<1 \mu \mathrm{m}$ size fraction were determined. There are virtually no data in the literature for the significance of the $<1 \mu \mathrm{m}$ size fraction in estuaries. The value of $6 \%$ obtained in this study shows the relatively minor importance of picophytoplankton in temperate estuarine waters in comparison to their impact on the primary production in oceanic oligotrophic waters, where the $<1 \mu \mathrm{m}$ size fraction has been shown to account for up to $80 \%$ of the plankton community rate of carbon uptake and chl a biomass (Li et al. 1983, Legendre et al. 1988, Odate \& Maita 1988).

A comparison among size fractions showed clearly that the $<1 \mu \mathrm{m}$ size fraction accounted for a larger proportion of total carbon fixation rate than of total chl a biomass. This can be interpreted that chl-a-specific rates of primary production are higher for the $<1 \mathrm{\mu m}$ fraction than for the larger fractions and is likely related to the physiological advantages derived from the extremely small size, mainly a higher efficiency of 
photon absorption and of nutrient uptake (Caperon \& Meyer 1972, Raven 1986). These higher chl-specific rates of carbon uptake for the $<1$ um size fraction have been observed in other studies in coastal and oceanic waters (Platt et al. 1983, Smith et al. 1985, Joint \& Pomroy 1986 . Howard \& Joint 1989). However, analytical bias related to poor extraction of chlorophyll from cyanobacteria (Stauffer et al. 1979) cannot be ruled out (Joint \& Pomroy 1986, Howard \& Joint 1989), and disagreements between values for chl concentration in the $<1 \mu \mathrm{m}$ size fraction calculated by size fractionation using differential filtration and by estimating picoalgal biovolumes and using $C$ :volume and $C$ : chl a conversion factors have been reported (Søndergaard et al. 1991).

\section{Factors controlling the seasonal size distribution of phytoplankton}

The clear differences in the seasonal distribution of chl a biomass and primary production rates observed for the various phytoplankton size classes examined showed that the factors controlling their seasonal cycles were also different.

The fact that at NW Netley irradiance was non-limiting for phytoplankton growth as early as March (sensu Riley 1967), together with the observation that during the April maximum of chl a at Calshot Spit (15.7 mg $\mathrm{m}^{-3}$ ) the level at NW Netley reached only $4.9 \mathrm{mg} \mathrm{m}^{-3}$, suggests that the Phaeocystis bloom was brought into the estuary with the tidal incursion. It can be hypothesized that light and temperature were probably adequate to trigger a bloom of the microphytoplankton offshore, but the low residence time of the water in the estuary hindered the growth of an autochthonous population of Phaeocystis until later in the season. The estuarine flushing time has previously been suggested to be the primary determinant of bloom development in this estuary (Souza Lima \& Williams 1978, Bryan 1979, Kifle \& Purdie 1993) and results from the present study suggest this was probably true for phytoplankton in the $>3 \mu \mathrm{m}$ size fraction.

The observation that during the summer chl a concentrations in the $>3 \mu \mathrm{m}$ fraction in the outer estuary were much lower than at the mid estuary station can be interpreted in relation to a stronger dilution effect by the offshore water coming in with the tidal incursion at the mouth of the estuary, water which is poorer in nutrient concentration and phytoplankton biomass (Collins 1978, Bryan 1979). Nitrogen did not appear to be limiting for phytoplankton growth at either of the 2 stations during summer, since, although ammonia levels were not monitored during this study, nitrate plus nitrite concentration alone was above the level that can be considered as limiting (sensu Fisher et al. 1988). However, phosphate concentrations were $<0.5 \mu \mathrm{M}$ during the summer at Calshot Spit, levels which may have limited the growth of phytoplankton $>3 \mu \mathrm{m}$ (sensu Fisher et al. 1988)

In contrast, the picophytoplankton cell concentration (both prokaryotic and eukaryotic) and the chl a biomass and production rate by the $<1 \mu \mathrm{m}$ size fraction all peaked in summer at both stations. Small phytoplankters have generally higher biomass-specific growth rates than larger phytoplankton (Banse 1976, Langdon 1988), and should theoretically be more succesful than the latter at both saturating and subsaturating levels of irradiance and nutrients. The question is then, why in spring, when physico-chemical conditions (i.e. temperature, irradiance, flushing time, nutrients) were adequate to trigger a bloom of microphytoplankton, did the biomass of picophytoplankton apparently not show a substantial increase?

Based both on seasonal and latitudinal variations many workers have been able to establish a positive relationship between abundance of picocyanobacteria and temperature (Murphy \& Haugen 1985, El Hag \& Fogg 1986, Waterbury et al. 1986, Jochem 1988, Odate 1989). However, this correlation was not very strong in the present study. As observed in other areas le.g. Menai Straits (N. Wales) and Irish Sea; El Hag \& Fogg 1986|, the increase to a maximum concentration of picocyanobacteria occurred rather suddenly, and suggests that although temperature may exert an influence, it is unlikely that a direct effect of temperature on the physiology of Synechococcus spp. is the only factor determining variations in its distribution and abundance. Furthermore, levels of Synechococcus greater than $10^{6}$ cells $1^{-1}$ have been recorded in the Arctic at temperatures below $0^{\circ} \mathrm{C}$ (Smith et al. 1985) and Shapiro \& Haugen (1988) reported a winter peak of Synechococcus concentration in Boothbay Harbor (Maine, USA). In this case the existence of a cold northern race with low temperature tolerance has been suggested as a possible explanation (Shapiro \& Haugen 1988).

We have no data in the present study on concentrations of possible consumers of picophytoplankton and their grazing rates, but it has been suggested that picophytoplankton are possibly more tightly controlled by grazing than larger phytoplankton (Goldman 1988, Thingstad \& Sakshaug 1990, Søndergaard et al. 1991). Peaks of picocyanobacteria in summer may be explainable as transient imbalances between growth rates and grazing rates at times when the temperature-enhanced growth rates of picocyanobacteria can outpace nanoheterotrophic grazing rate and/or the increased food concentration for nanoflagellates (i.e. increased bacterial concentration in summer) results in a release in 
grazing pressure on picocyanobacteria. Furthermore, nanoflagellates themselves are probably under greater grazing pressure by microzooplankters during summer (e.g. McManus \& Fuhrman 1990).

An important difference to note is that whilst it is possible that larger phytoplankton were phosphate limited in the outer estuary during summer, the $<1 \mathrm{fm}$ size fraction was clearly neither phosphorus nor nitrogen limited. An inverse relationship between primary production rate by the picophytoplankton and the nutrient concentration has already been noted in coastal areas (e.g. Funka Bay; Maita \& Odate 1988).

When analyzing the contribution of the $<1 \mu \mathrm{m}$ size fraction to total plankton community chl a biomass and primary production rate, it is evident that this was highest during periods of low overall chl a biomass and primary production rate. This trend of variation ob- served on a seasonal basis has also been observed for chl a biomass on a spatial basis in Southampton Water (Iriarte 1993). As we can see from Table 6 this is a very generalized pattern, which is manifested both in spatial (small and large scale) as well as in temporal gradients. From data presented in Table 6 we can broadly say that in the marine environment photosynthetic picoplankton is usually the dominant fraction of the phytoplankton (>50\%) in waters where total chl a concentration is less than $0.5 \mathrm{mg} \mathrm{m}^{-3}$. At levels of 0.5 to $1 \mathrm{mg} \mathrm{m}^{-3}$ of total chl a the photosynthetic picoplankton accounts for 20 to $50 \%$ of the total chl a concentration. Between 1 and $5 \mathrm{mg} \mathrm{m}^{-3}$ total chl a biomass, the picoplankton fraction is generally responsible for 5 to $20 \%$ of it and at high concentrations of total chl a (i.e. $>5 \mathrm{mg} \mathrm{m}^{-3}$ ) the photosynthetic picoplankton becomes a minor component (i.e. $<5 \%$ ). From these considera-

Table 6 . Relationship between total chl a biomass, nitrate concentration and the percentage contribution of picophytoplankton to total chl a concentration for various oceanographic provinces

\begin{tabular}{|c|c|c|c|c|c|}
\hline $\begin{array}{l}\text { Total chl } \\
\left(\mathrm{mg} \mathrm{m}^{-3}\right)\end{array}$ & $\begin{array}{l}\text { Nitrate } \\
\text { ( } \mu \mathrm{M})\end{array}$ & $\begin{array}{l}\text { Size } \\
(\mu \mathrm{m})\end{array}$ & $\begin{array}{l}\mathrm{Chl} \\
(\%)\end{array}$ & Location & Source \\
\hline$<1$ & & $<1$ & ca $50-90$ & Tropical Pacific & Li et al. (1983) \\
\hline $\begin{array}{l}<0.05-0.25 \\
\quad>0.25\end{array}$ & $\begin{array}{l}<0.1 \\
>0.1\end{array}$ & $\begin{array}{l}<1 \\
<1\end{array}$ & $\begin{array}{l}71 \\
40\end{array}$ & Equatorial Atlantic & Herbland et al.(1985) \\
\hline $\begin{array}{c}0.05-0.4 \\
3.86\end{array}$ & $\begin{array}{l}- \\
-\end{array}$ & $\begin{array}{l}<2 \\
<2\end{array}$ & $\begin{array}{c}51-84 \\
29\end{array}$ & NW Pacific & Odate \& Maita (1988) \\
\hline $0.07-0.52$ & - & $<2$ & $59-80$ & Coral Sea & Furnas \& Mitchell (1988) \\
\hline $0.11-0.17$ & $0.2-0.6$ & $<1$ & $56-63$ & Strait of Messina & Magazzú et al. (1987) \\
\hline $\begin{array}{l}<1 \\
1-5\end{array}$ & $\begin{array}{l}- \\
-\end{array}$ & $\begin{array}{l}<1 \\
<1\end{array}$ & $\begin{array}{l}\text { ca } 40 \\
\text { ca } 20\end{array}$ & $\begin{array}{l}\text { Ligurian Sea } \\
\text { Algerian Basin }\end{array}$ & Raimbault et al. (1988) \\
\hline $\begin{array}{l}0.3-0.5 \\
0.5-1 \\
1-5 \\
>5\end{array}$ & $\begin{array}{l}<1 \\
<1 \\
<1 \\
<1\end{array}$ & $\begin{array}{l}<2 \\
<2 \\
<2 \\
<2\end{array}$ & $\begin{array}{c}58-92^{a} \\
31-58^{a} \\
7-31^{a} \\
<7^{a}\end{array}$ & $\begin{array}{l}\text { Danish coastal } \\
\text { waters }\end{array}$ & Sendergaard et al. (1991) \\
\hline $\begin{array}{l}1.1-3.8 \\
4.3-9.1\end{array}$ & $\begin{array}{l}1.1-8.7 \\
1.1-8.7\end{array}$ & $\begin{array}{l}<1 \\
<1\end{array}$ & $\begin{array}{c}10-18 \\
4-7\end{array}$ & $\begin{array}{l}\text { Gyeanggi Bay } \\
\text { (Yellow Sea) }\end{array}$ & Shim \& Kahng (1986) \\
\hline $\begin{array}{c}<1 \\
1-4.1\end{array}$ & $\begin{array}{l}<2 \\
-\end{array}$ & $\begin{array}{l}<2 \\
<2\end{array}$ & $\begin{array}{c}28-57 \\
<10\end{array}$ & $\begin{array}{l}\text { Funka Bay } \\
\text { (Japan) }\end{array}$ & Maita \& Odate (1988) \\
\hline $\begin{array}{l}2.5 \\
1.1 .6\end{array}$ & $\begin{array}{l}- \\
-\end{array}$ & $\begin{array}{l}<1 \\
<1\end{array}$ & $\begin{array}{l}6.5 \\
1.5\end{array}$ & $\begin{array}{l}\text { Concepción Bay } \\
\text { (Chile) }\end{array}$ & Gonzalez et al. (1989) \\
\hline $\begin{array}{c}6-13 \\
1-6\end{array}$ & $\begin{array}{l}9-256 \\
11-53\end{array}$ & $\begin{array}{l}<1 \\
<1\end{array}$ & $\begin{array}{r}1.7-3 \\
3-9\end{array}$ & $\begin{array}{l}\text { Southampton } \\
\text { Water estuary }\end{array}$ & Iriarte (1993) \\
\hline $0.9-3.1$ & - & $<1$ & $1.5-7.8$ & $\begin{array}{l}\text { Upwelled waters } \\
\text { off Ivory Coast }\end{array}$ & Herbland et al. (1985) \\
\hline
\end{tabular}


tions it can be suggested that large variations in overall phytoplankton biomass and primary production are mainly controlled by variations in biomass of phytoplankton larger than picoplankton, and that therefore the relative contribution of the different size classes, i.e. the size structure of the phytoplankton community, is primarily influenced by the concentration of phytoplankton larger than picoplankton. Results from other studies have also suggested these conclusions (Odate \& Maita 1988, Gonzalez et al. 1989, Søndergaard et al. 1991, Iriarte \& Purdie 1993). Factors limiting the accumulation of large phytoplankton cells thus appear to be the primary determinants of an increase in the relative significance of picophytoplankton. Modelling studies have suggested that above a certain nutrient concentration the increase in nutrient input is a main controlling factor for the increase in the relative importance of large phytoplankton (Thingstad \& Sakshaug 1990). In agreement with this consideration, in Southampton Water in the outer area of the estuary, the significance of picoplankton was greatest during summer, when large phytoplankton were possibly nutrient limited. In the inner station, however, both nitrogen and phosphorus were at non-limiting concentrations during the entire sampling period and the $<1 \mu \mathrm{m}$ fraction reached its highest contribution to overall plankton community primary production rate during autumn and winter, when it is likely that irradiance became comparatively more limiting to larger than to smaller phytoplankton cells. Chavez (1989) has found low concentrations of large diatoms in deep-sea upwelling areas and has suggested that the absence of seed cells due to the absence of a continental shelf is more decisive than the nutrient limitation in determining the dominance of small phytoplankton in deep-sea waters.

Acknowledgements. We thank D. Kifle and D. Hutchinson for assistance in the field and the laboratory. We also thank 3 anonymous reviewers for their constructive comments. The first author (A.I.) was supported by a postgraduate grant from the Departamento de Educación, Universidades e Investigación del Gobierno Vasco.

\section{LITERATURE CITED}

Banse, K. (1976). Rates of growth, respiration and photosynthesis of unicellular algae as related to cell size - a review. J. Phycol. 12: 135-140

Bryan, J. R. (1979). The production and decomposition of organic material in an estuary - Southampton Water. Ph.D. thesis, University of Southampton

Caperon, J., Meyer, J. (1972). Nitrogen-limited growth of marine phytoplankton. II. Uptake kinetics and their role in nutrient limited growth of phytoplankton. Deep Sea Res. 19: $619-632$

Chavez, F. P. (1989). Size distribution of phytoplankton in the central and eastern tropical Pacific. Global biogeochem. Cycles 3: 27-35

Chisholm, S. W., Ilsen, R. J., Zettler, E. R., Goericke, R., Waterbury, J. B., Welschmeyer, N. A. (1988). A novel free-living prochlorophyte abundant in the oceanic euphotic zone. Nature 334: $340-344$

Collins, K. J. (1978). The fluxes of organic carbon and nutrients in Southampton Water. Ph.D. thesis, University of Southampton

El Hag, A. G. D., Fogg, G. E. (1986). The distribution of coccoid blue-green algae (Cyanobacteria) in the Menai Straits and the Irish Sea. Br. Phycol. J. 21: 45-54

Fisher, T R., Harding, L. W. Jr, Stanley, D. W., Ward, L. G. (1988). Phytoplankton, nutrients and turbidity in the Chesapeake, Delaware and Hudson estuaries. Estuar. coast. Shelf Sci. 27:61-93

Furnas, M. J., Mitchell, A. W. (1988). Photosynthetic characteristics of Coral Sea picoplankton $(<2 \mu \mathrm{m}$ size fraction). Biol. Oceanogr. 5: 163-182

Garcia, V. M. T., Purdie, D. A. (1992). The influence of irradiance on growth, photosynthesis and respiration of Gyrodinium cf. aureolum. J. Plankton Res. 14: 1251-1265

Gieskes, W. W. C., Kraay, G. W., Baars, M. A. (1979). Current ${ }^{14} \mathrm{C}$ methods for measuring primary production: gross underestimates in oceanic waters. Neth. J. Sea Res. 13: $58-78$

Glover, H. E., Campbell, L., Prezelin, B. B. (1986). Contribution of Synechococcus spp. to size-fractionated primary productivity in three water masses in the Northwest Atlantic Ocean. Mar. Biol. 91. 193-203

Goldman, J. C. (1988). Spatial and temporal discontinuities of biological processes in pelagic surface waters. In: Rothschild, B. J. (ed.) Toward a theory in biological-physical interactions in the world ocean. Kluwer Academic Publishers, Dordrecht, p. 273-296

Gonzalez, H., Pantoja, S., Iriarte, J. L., Bernal, P. A. (1989). Winter-spring variability of size-fractionated autotrophic biomass in Concepción Bay, Chile. J. Plankton Res. 11: $1157-1167$

Hargraves, P. E., Vaillancourt, R. D., Jolly, G. A. (1989). Autotrophic picoplankton in Narragansett Bay and their interaction with microplankton. In: Cosper, E. M., Bricelj, V. M., Carpenter, E. J. (eds.) Novel phytoplankton blooms: causes and impacts of recurrent brown tides and other unusual blooms. Springer-Verlag, Berlin, p. 23-38

Herbiand, A., Le Bouteiller, A., Raimbault, P. (1985). Size structure of phytoplankton biomass in the equatorial Atlantic Ocean. Deep Sea Res. 32: 819-836

Howard, K. M., Joint, l. R. (1989). Physiological ecology of picoplankton in the North Sea. Mar. Biol. 102: 275-281

Iriarte, A. (1993). Size fractionated chlorophyll $a$ biomass and picophytoplankton cell density along a longitudinal axis of a temperate estuary (Southampton Water). J. Plankton Res. 15: 485-500

lriarte, A., Purdie, D. A. (1993). Distribution of chroococcoid cyanobacteria and size fractionated chlorophyll a biomass in central and southern North Sea waters during June/ July 1989. Neth. J. Sea Res. 31: 53-56

Jochem, F. (1988). On the distribution and importance of picocyanobacteria in a boreal inshore area (Kiel Bight, Western Baltic). J. Plankton Res. 16: 1009-1022

Jochem, F. (1989). Distribution and importance of autotrophic ultraplankton in a boreal inshore area (Kiel Bight, Western Baltic). Mar. Ecol. Prog. Ser. 53: 153-168

Johnson, K. S., Petty, R. L. (1983). Determination of nitrate and nitrite in seawater by flow injection analysis. Limnol. Oceanogr. 28: 1260-1266 
Johnson, P. W., Sieburth, J. M. (1979). Chroococcoid cyanobacteria in the sea: a ubiquitous and diverse phototrophic biomass Limnol. Oceanogr. 24: 928-935

Joint, I. R., Owens, N. J. P., Pomroy, A. J. (1986). Seasonal production of photosynthetic picoplankton and nanoplankton in the Celtic Sea. Mar. Ecol. Prog. Ser. 28: 251-258

Joint, I. R., Pomroy, A. J. (1986). Photosynthetic characteristics of nanoplankton and picoplankton from the surface mixed layer. Mar. Biol. 92: 465-474

Kifle, D., Purdie, D. A. (1993). The seasonal abundance of the phototrophic ciliate Mesodinium rubrum in Southampton Water, England. J. Plankton Res. 15: 823-833

Kuosa, H. (1988). Occurrence of autotrophic picoplankton along an open sea-inner archipelago gradient in the Gulf of Finland, Baltic Sea. Ophelia 28: 85-93

Kuosa, H. (1991). Picoplankton algae in the northern Baltic Sea: seasonal dynamics and flagellate grazing. Mar. Ecol. Prog. Ser 73: 269-276

Lancelot, C. (1983). Factors affecting extracellular release in the southern Bight of the North Sea. Mar. Ecol. Prog. Ser. 12: $115-121$

Lancelot, C., Mathot, S., Owens, N. J. P. (1986). Modelling protein synthesis, a step to an accurate estimate of net primary production: the case of Phaeocystis pouchetii colonies in Belgian coastal waters. Mar. Ecol, Prog. Ser. 32: 193-202

Langdon, C. (1988). On the causes of interspecific differences in the growth-irradiance relationship for phytoplankton. II. A review. J. Plankton Res. 10: 1291-1312

Larsson, U., Hagström. А. (1982). Fractionated primary production, exudate release and bacterial production in a Baltic eutrophication gradient. Mar. Biol. 67: 57-70

Legendre, L., Demers, S., Delesalle, B., Harnois, C. (1988). Biomass and photosynthetic activity of phototrophic picoplankton in coral reef waters (Moorea Island, French Polynesia). Mar. Ecol. Prog. Ser. 47: 153-160

Li, W. K. W. (1986). Experimental approaches to field measurements: methods and interpretation. In: Platt, T., Li, W. K. W. (eds.) Photosynthetic picoplankton. Can. Bull. Fish. Aquat. Sci. 214: 251-286

Li, W. K. W., Subba Rao, D. V., Harrison, W. G., Smith, J. C., Cullen, J. J., Irwin, B., Platt, T (1983). Autotrophic picoplankton in the tropical ocean. Science 219: 292-295

Li, W. K. W. Wood, A. M. (1988). Vertical distribution of North Atlantic ultraphytoplankton: analysis by flow cytometry and epifluorescence microscopy. Deep Sea Res. 35: 1615-1638

Lindholm, T (1985). Mesodinium rubrum - a unique photosynthetic ciliate. Adv. aquat. Microbiol. 3: 1-48

Madariaga, I. de, Orive, E. (1989). Spatio-temporal variations of size-fractionated primary production rate in the Gernika estuary. J. exp. mar. Biol. Ecol. 127: 273-288

Magazzù, G., Bruni, V., Piccione, A., Platt, T., Irwin, B., Subba Rao, D. V. (1987). Picoplankton: contribution to phytoplankton production in the Strait of Messina. P.S.Z.N. I: Mar. Ecol. 8: 21-31

Maita, Y., Odate, T (1988). Seasonal. changes in size-fractionated primary production and nutrient concentrations in the temperate neritic water of Funka Bay, Japan. J. Oceanogr. Soc. Japan 44: 268-279

Malone, T. C. (1980). Size fractionated primary productivity of marine phytoplankton. In: Falkowski, P. G. (ed.) Primary productivity in the sea. Plenum Press, New York, p. 301-319

McManus, G. B., Fuhrman, J. A. (1990). Mesoscale and seasonal variability of heterotrophic nanoflagellate abundance in an estuarine outflow plume. Mar. Ecol. Prog. Ser 61: $207-213$
Murphy, L. S., Haugen, E. M. (1985). The distribution and abundance of phototrophic ultraplankton in the North Atlantic. Limnol. Oceanogr 30: 47-58

Odate, T (1989). Seasonal changes in cell density of cyanobacteria and the picophytoplankton populations in Funka Bay, Japan. Bull. Plankton Soc. Japan 36: 53-61

Odate, T., Maita, Y. (1988). Regional variation in the size composition of phytoplankton communities in the western North Pacific ocean, spring 1985. Biol. Oceanogr. 6: 65-77

O'Reilly, J. E., Thomas, J. P. (1983). A manual for the measurements of total daily primary productivity. Biomass Handbook 10, SCAR/SCOR/IABO/ACMRR Group of specialists on living resources of the southern oceans

Parsons, T R., Maita, Y., Lalli, C. M. (1984). A manual of chemical and biological methods for seawater analysis. Pergamon Press, Oxford

Pilgrim, D. A. (1987). Measurement and estimation of the extinction coefficient in turbid estuarine waters. Cont. Shelf Res. 7: 1425-1428

Platt, T., Gallegos, C. L., Harrison, W. G. (1980). Photoinhibition of photosynthesis in natural assemblages of marine phytoplankton. J. mar. Res. 38: 687-701

Platt, T., Subba Rao, D. V., Irwin, B. (1983). Photosynthesis of picoplankton in the oligotrophic ocean. Nature 301 $702-704$

Raimbault, P., Rodier, M., Taupier-Letage, I. (1988). Size fraction of phytoplankton in the Ligurian Sea and the Algerian Basin (Mediterranean Sea): size distribution versus total concentration. Mar. microb. Food Webs 3:1-7

Raven, J. A. (1986). Physiological consequences of extremely small size for autotrophic organisms in the sea. In: Platt, T., Li, W. K. W. (eds.) Photosynthetic picoplankton. Can. Bull. Fish. Aquat. Sci. 214: 1-70

Ray, R. T., Haas, L. W., Sieracki, M. E. (1989). Autotrophic picoplankton dynamics in a Chesapeake Bay sub-estuary. Mar. Ecol. Prog. Ser. 52: 273-285

Riley, G. A. (1967). The plankton of estuaries. In: Lauff, G. H. (ed.) Estuaries. Publ. Am. Assoc. Adv. Sci., Washington, DC, p. 316-326

Selmer, J.-S., Ferrier-Pages, C., Cellario, C., Rassoulzadegan, F. (1993). New and regenerated production in relation to the microbial loop in the NW Mediterranean Sea. Mar. Ecol. Prog. Ser. 100: 71-83

Shapiro, L., Haugen, E. M. (1988). Seasonal distribution and temperature tolerance of Synechococcus in Booth Bay Harbor, Maine. Estuar. coast. Shelf Sci. 26: 517-525

Shim, J. H., Kahng, S. H. (1986). A comparative study of primary production by using the ${ }^{14} \mathrm{C}$ and oxygen methods. J. Oceanol. Soc. Korea 21:73-84

Sieburth, J. MCN. (1984). Protozoan bacterivory in pelagic marine waters. In: Hobbie, J. E., Williams, P. J. LeB. (eds.) Heterotrophic activity in the sea. Plenum. Press, New York, p. 405-444

Sieburth, J. McN., Smetacek, V., Lenz, J. (1978). Pelagic ecosystem structure: heterotrophic compartments of the plankton and their relationship to plankton size. Limnol. Oceanogr 23: 1256-1263

Sinclair, M. (1978). Summer phytoplankton variability in the lower Saint-Lawrence estuary. J. Fish. Res. Bd Can. 35: $1171-1.185$

Smith, J. C., Platt, T., Li, W. K. W., Horne, E. P. W., Harrison, W. G., Subba Rao, D. V., Irwin, B. D. (1985). Arctic marine photoautotrophic picoplankton. Mar. Ecol. Prog. Ser, 20: $207-220$

Smith, W. O., Barber, R. T. (1979). A carbon budget for the autotrophic ciliate Mesodinium rubrum. J. Phycol. 15: 27-33 
Sondergaard, M., Jensen, L. M., Ertebjerg, G. (1991). Picoalgae in Danish coastal waters during summer stratification. Mar. Ecol. Prog. Ser. 79: 139-149

Sorokin, Y. I. (1971). On the role of bacteria in productivity of tropical ocean waters. Int. Rev. ges. Hydrobiol. 56: 1-48

Souza Lima, H. de, Williams, P. J. leB. (1978). Oxygen consumption by the planktonic population of an estuary, Southampton Water. Estuar. coast. mar. Sci. 6: 515-523

Stauffer, R. E., Lee, G. F., Armstrong, D. E. (1979). Estimating chlorophyll extraction biases. J. Fish. Res. Bd Can. 36: $152-157$

Steemann Nielsen, E. (1952). The use of radioactive carbon $\left({ }^{14} \mathrm{C}\right)$ for measuring organic production in the sea. J. Cons. Explor. Mer 18: 117-140

Thingstad, T. F., Sakshaug, E. (1990). Control of phytoplank-

This article was submitted to the editor ton growth in nutrient recycling ecosystems. Theory and terminology. Mar. Ecol. Prog. Ser. 63: 261-272

Throndsen, J. (1978). Productivity and abundance of ultraand nanoplankton in Oslofjorden. Sarsia 63: 273-284

Waterbury, J. B., Watson, S. W., Guillard, R. R. L., Brand, L. E (1979). Widespread occurrence of a unicellular, marine, planktonic cyanobacterium. Nature 277. 293-294

Waterbury, J. B., Watson, S. W., Valois, F. W., Franks, D. G (1986). Biological and ecological characterization of the marine unicellular cyanobacterium Synechococcus. In: Platt, T., Li, W K. W. (eds.) Photosynthetic picoplankton Can. Bull. Fish. Aquat. Sci. 214: 71-120

Wilhelm, C., Eisenbeis, G., Wild, A., Zahn, R. (1982). Nanochlorum eukaryotum: a very reduced coccoid species of marine Chlorophyceae. Z. Naturforsch. 37C: 107-114

Manuscript first received: November 23, 1993

Revised version accepted: September 13, 1994 